\title{
Energy efficiency and steam coal transport over long distances
}

\author{
Katarzyna Stala-Szlugaj ${ }^{1 a}$ and Zbigniew Grudzinski ${ }^{1}$ \\ ${ }^{1}$ The Mineral and Energy Economy Research Institute of the Polish Academy of Sciences, Krakow, Poland
}

\begin{abstract}
Coal is one of the most important energy sources in the world. Its main consumers are the energy sector (with a $37-46 \%$ share in the years $1990-2014 ; 1.12-2.34$ billion toe) and industry (24-27\%; 0.78-1.38 billion toe). Diversified distribution of coal deposits in the world in relation to its consumers means that it has to be transported over often very long distances. The global coal trade is dominated by maritime transport (90-94\% in the years 2004-2014), and the share of transport by land is relatively smaller. The aim of the article was to calculate the index describing what part of the energy contained in the coal transported on a particular route is consumed by the train carrying it. Due to the dominant position of the Russian Federation in imports of coal to Poland, it was assumed that coal will be imported by rail from Kuzbass (Russia's largest coal basin). As a result of the calculation, it was found that the rate of energy consumption for transport of imported coal will be somewhere in the range of $9.22-15.26 \%$. In the case of deliveries of hard coal from Polish producers to the power plants the calculated rate changes within the range of $0.55-0.58 \%$.
\end{abstract}

\section{Introduction}

Coal, following liquid fuels and natural gas, is the third most important energy carrier used in the world. According to the data for 2014 [1] its share in the global consumption was $30 \%$ (4.01 billion toe). Although in comparison to 1990 , its share increased by only 3 percentage points, the total world consumption of coal increased by 1.65 billion toe (an increase of $74 \%$ ). It is anticipated [1] that in 2035 global coal consumption will reach 4.27 billion toe, and its share will drop to $25 \%$.

The main consumer of coal is the energy sector with $37-46 \%$ share in the years 1990-2014 (1.12-2.34 billion toe). It is followed by the industry sector $(24-27 \%$; 0.78 1.38 billion toe) and other sectors $(26-38 \% ; 1.23-1.30$ billion toe). According to forecasts [1] in 2035, the use of coal as feedstock for energy transformations will reach 2.49 billion toe and - in comparison with 2014 will increase by 274 million toe (an increase of $20 \%$ ). The main contributors to the decrease in coal consumption in the world will be the economy rebalance and the decline in GDP growth in China, as well as the tightening of environmental policy.

Diversified distribution of coal deposits in the world in relation to its consumers means that it has to be transported over often very long distances. The global coal trade is dominated by maritime transport (Fig. 1). In the years 2004-2014, this way accounted for $90-94 \%$ of international trade, while the remainder was transported by land.

International markets for coal are usually divided into two regions: Pacific and Atlantic. The Pacific market's major exporters of coal include: Australia, Indonesia

${ }^{a}$ Corresponding author: kszlugaj@min-pan.krakow.pl and China, and the main consumers are Japan, South Korea and Taiwan. In the Atlantic market coal reaches Europe by sea primarily from: South Africa, Colombia, Indonesia, Venezuela and the United States. Poland and the Russian Federation are also important suppliers of coal to the European market.

In the years 2004-2014 the total volume of global trade by sea varied between 73 and 92 million tons of coal (Fig. 1), and its share decreased from 10\% (in 2004) to 7\% (2014).

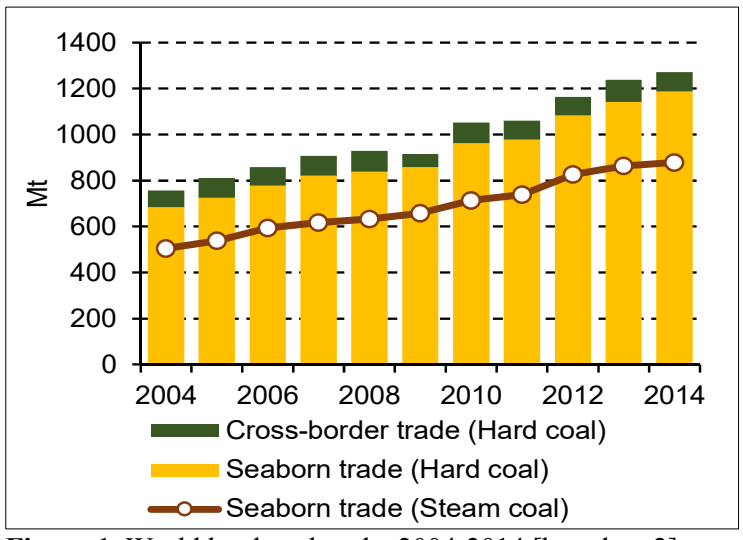

Figure 1. World hard coal trade, 2004-2014 [based on 2]

Due to the high concentration of producers and consumers, coal trade by land usually takes place between the countries situated on the Eurasian continent.

The international market is dominated by sales of steam coal (Fig. 1). In the years 2004-2014, its share in the global trade by sea varied from 74 to $77 \%$. 
In quantitative terms, turnover increased from 505 (in 2004) to 878 million tonnes (2014).

In the case of Poland, relatively close proximity of the main exporters of coal (the Russian Federation and the Czech Republic) makes the rail transport the most common way of coal imports.

Due to the dominant position of the Russian Federation in coal exports to the Polish market, the objective of this article is to determine the share of energy associated with the transport of coal from the Russian Federation to Poland, in relation to the energy contained in the imported coal.

\section{Import of steam coal to Poland}

For many years, Poland was one of the leading exporters of hard coal in the world. In the years 1966-1978 the Polish participation in the international coal market averaged as much as $19 \%$. In recent years, Poland was ranked in 9th-10th place on the global scale (with a share of $1-2 \%$ ), while exports amounted to about 7-11 million tonnes. Mainly steam coal is exported from the country (Fig. 2). In the years 1990-2015 it constituted from 60 to $86 \%$ of the exported tonnage.

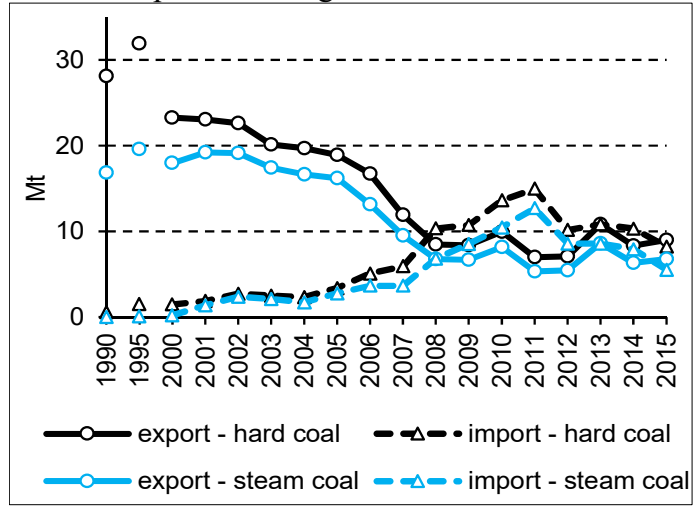

Figure 2. Poland - export and import of hard and steam coal [based on 3, 4]

Before the Polish accession to the European Union, import of hard coal was low. By 1995, it amounted to only a little more than 1 million tons (Fig. 2). Only coking coal, which is used for producing coke, was brought to the country. The increase in coal imports in the $90 \mathrm{~s}$ of the 20th century (up to approx. 2-4 million tons) was associated with the economic and political transformation in the country. The process of restructuring the hard coal mining industry began at that time [i.e. 5, 6, 7, 8, 9]. A number of legal acts [i.e. 10,11, 12, 13] were passed to protect Poland against excessive imports of coal and quotas on imports of coal from the Russian Federation and the Czech Republic were introduced [i.e. 14, 15, 16, $17,18,19]$.

With the Polish access to the EU in 2004, the acts protecting Poland against the increased imports of coal lost their legal force [20]. The protection from imports now applied to the whole EU market.

In order to achieve economic efficiency, the Polish mining industry underwent subsequent stages of restructuring. Efforts of the recovery programs together with simultaneous shortages of necessary investments in development works led to a situation where there was a shortage of domestic coal in the market [7, 21]. In 2006-2007 there was an increase in steam coal consumption in the power industry. As a consequence of the underestimation of the needs of the energy sector (lack of relevant mining contracts for delivery in 2007), a threat of a shortage of steam coal occurred. At the expense of export contracts and a reduction in the supply of coal to non-contractual customers, the mining industry complied with its obligations.

However, the domestic customers were left with the impression of "uncertainty" of supplies from domestic producers. As a result, both big and individual consumers of coal began searching for supplies of this material among foreign producers. This situation was used by small coal importers, who have found a source of supply, especially among the CIS countries (The Commonwealth of Independent States). At the same time the profitability of coal imports to Poland was reinforced by the weak position of the US dollar against majority of national currencies.

The consequences of increased imports manifested in 2008 (see Fig. 2), in which Poland for the first time in history became a net importer. In comparison to the previous year, imports of hard coal increased by as much as $75 \%$.

The greatest amount of hard coal (15 million tonnes), was imported to Poland in 2011, of which $85 \%$ was steam coal. According to [22], that year the ratio of Poland's dependence on imports of hard coal was more than $10 \%$.

The main exporters of steam coal to the Polish market are the Russian Federation and the Czech Republic (Figure $3)$. In the years 2004-2014 imports of stem coal ranged from 1.7 to 12.7 million tonnes. Out of that, the two mentioned countries provided (respectively): 73-91\% and $1-17 \%$ of the material imported to Poland.

The geographical location of the exporters in relation to Poland makes rail transport most convenient. In recent years, this means of transport is responsible for about $70 \%$ of the raw material imported to Poland $[23,24]$. Coal imported from CIS countries usually crossed the Polish border at railway crossing with the Russian Federation (Braniewo) and Belarus (Kuznica Bialostocka, Terespol). From the Czech Republic it entered Poland through the crossings in Chalupki and Zebrzydowice.

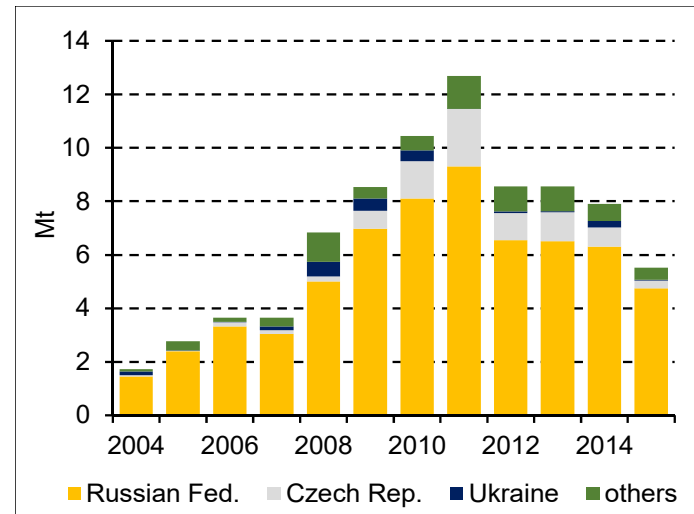

Figure 3. Major steam coal exporters to Poland [based on 3, 4] 
In the case of the largest supplier to the Polish market - the Russian Federation - the raw material is mainly imported from the largest coal basin called Kuzbass. The average distance for the train from Kuzbass to Poland is about five thousand kilometers (Fig. 4). In order to reach the crossings in the north-eastern part of Poland, the train must pass through the territory of Belarus and / or Lithuania.

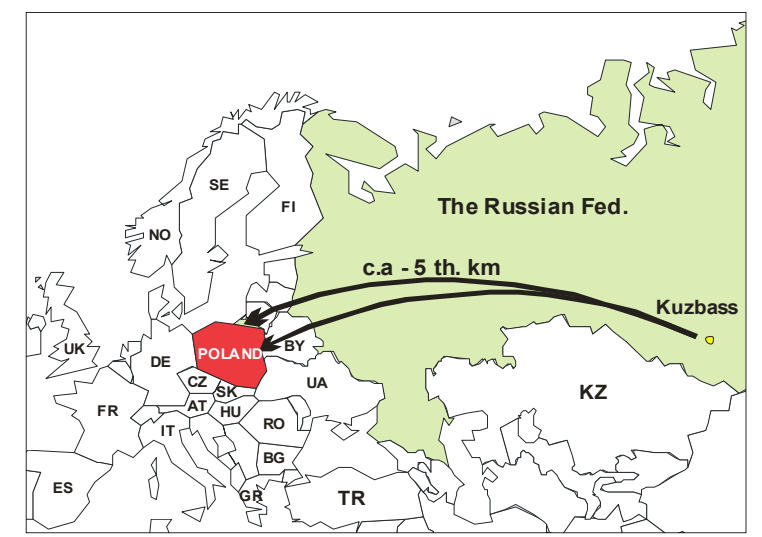

Figure 4. Estimated hard coal transport route from Kuzbass to Poland [own work]

\section{Railway Transportation of coal}

One of the types of land transport used for transportation of coal is a railway. The advantage of this transport is that it can carry large mass of load.

With the development of railways in the world, a number of railway lines with different track gauge were built. Track gauge is the distance between the inner rails, measured $14 \mathrm{~mm}$ below the upper surface of the rail's head [25].

In general, the division associated with the spacing of the rails allows for distinguishing the following types of railway lines [25]:

- standard gauge lines - are characterized by the most popular track gauge of $1435 \mathrm{~mm}$ (this is called normal gauge of the track, which is adopted in most European countries),

- broad gauge lines - these are all tracks, whose distance between the rails is higher than normal, i.e. over 1435 $\mathrm{mm}$. Increasing the width of the track was initiated in Tsarist Russia which, in order to obstruct the entry to its territory by rail, began to build tracks with gauge of $1520 \mathrm{~mm}$. Among other European countries with the broad gauge lines of a different spacing one may mention Spain and Ireland (1676 mm).

- narrow-gauge lines - the spacing between the rails is less than the normal gauge. The most common gauge of these lines is $1000 \mathrm{~mm}$. Similarly as in the case of broad-gauge lines, there is a great diversity of gauge and their place of operation. There are about 120 different track widths of narrow gauge in the world.

As shown in chapter 2, the largest exporter of coal to the Polish market is the Russian Federation. The geographic location of this exporter in relation to Poland allows for the use of rail transport.
Both in Poland and in the Russian Federation hard coal is the most important cargo transported by rail. In Poland in the period of 2004-2014 railway was used for transporting from 152.3 million tonnes (2004) to 84.3 million tons (in 2009). Transportation of hard coal in 2014 amounted to 94.5 million tons, and in comparison with 2004 , decreased by 59.8 million tonnes.

The decrease in domestic coal production in Poland was reflected in the reduction of the share of hard coal in the total mass of cargo transported by rail. In the years 2004-2014, this share has fallen from 55\% (in 2005) to $38 \%$ (in 2007) (Fig. 5). A significant increase in carriage in 2008 (by 7 percentage points compared y / y) resulted from the aforementioned increase in coal imports.

In the case of the Russian Federation, both the mass of transported hard coal and its share in the total transportation increased. For the last eleven years, the railway transport of hard coal has increased from 273.5 (in 2004) to 315.4 million tonnes (2014). Its share in the overall tonnage increased from $22 \%$ (in the years 2004-2006) to 26\% in 2014 (see Fig. 4).

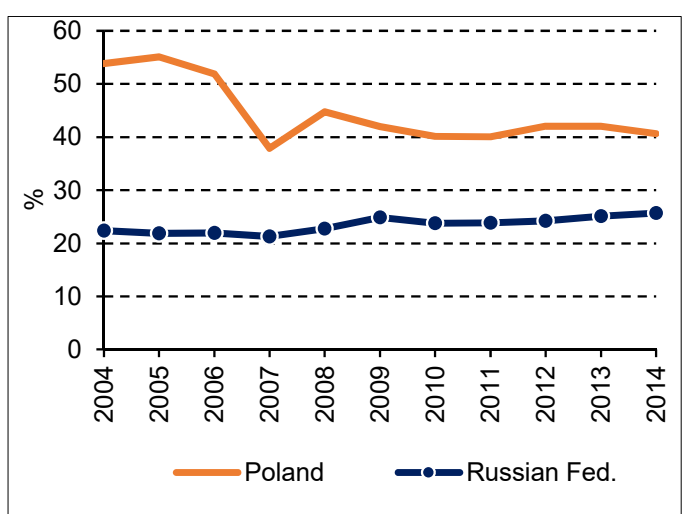

Figure 5. The share of hard coal in rail transport in Poland and in the Russian Federation [own work based on 26, 27]

In the Russian Federation, for the transport of dry bulk goods (coal, ore, wood and such types of goods that do not pollute the atmosphere) so-called coal-wagons are used [Russian: poluwagony]. Among them 4, 6 and 8-axis wagons are distinguished. The bearing capacity for these types of wagons varies within a wide range - from 62 tons to 125 tonnes [28, 29].

The length of the train and its weight is dependent on the parameters of the railway lines and the length of station tracks. In the case of trains carrying coal, the longest trainsets can currently be found, among others,

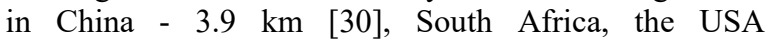
and Australia - more than $2 \mathrm{~km}[31,32,33]$. In the Russian Federation the average trainset length is $806 \mathrm{~m} \mathrm{[34],}$ and in Poland $-600 \mathrm{~m}$.

\section{Calculations}

The aim of the article was to calculate the index describing what part of the energy contained in the coal transported on a particular route is consumed by the train carrying it.

It was assumed that steam coal will be transported by rail from Kuzbass to Poland. The entire cargo of coal would be used to produce electricity, and the train will 
return without load. Therefore, this indicator will take into account the work of the train on the route back and forth.

In order to accomplish this task one needs to know how much energy is consumed by trains transporting coal from the Russian Federation to Poland. Because the detailed specification of the train's route is unknown, this article is based on empirical indicators calculated on the basis of data from the actual freight trains from the paper [35].

The authors are aware that in order to calculate the amount of electricity consumed by a freight train, one should base on complicated formulas presented in many publications [i.e. 36, 37, 38, 39]. They must, among others, take into account the driving force of the locomotive (eg. Chwieduk's formula), the resistance to the movement of the train (eg. Frank's, CNTK's, Davis' formulas), the braking forces, accelerating forces (eg. Wichter's, Chwieduk's formula), and many other factors.

Input data to calculate the electricity consumption for coal transportation by rail is presented in Table 1 . This is the actual data on how to select long-distance transport in Polish conditions. This data must include information on the consumption of electricity on the route, the train weight and the amount of distance traveled. It should refer to both directions of transport (destination / return).

Table 1. The data to calculations [35]

\begin{tabular}{|c|c|c|c|}
\hline \multirow{2}{*}{ Sample of route } & $\begin{array}{c}\text { Out/ } \\
\text { Return }\end{array}$ & $\begin{array}{c}\text { Av. } \\
\text { weight }\end{array}$ & $\begin{array}{l}\text { Av. elect. } \\
\text { consump. }\end{array}$ \\
\hline & $\mathrm{km}$ & $\mathrm{t}$ & $\mathrm{Wh} / \mathrm{tkm}$ \\
\hline Tarnowskie G.- Gdynia & 474 & $\frac{2297}{1235}$ & $\frac{11.30}{17.73}$ \\
\hline Warszawa - Poznań & 290 & $\frac{1963}{1282}$ & $\frac{10.90}{13.75}$ \\
\hline Kraków - Medyka & 237 & $\frac{2635}{1433}$ & $\frac{8.92}{12.42}$ \\
\hline Warszawa O. - Łazy & 271 & $\frac{2381}{1305}$ & $\frac{7.10}{15.40}$ \\
\hline
\end{tabular}

Table 1 shows that transport of cargo to the customer is associated with energy expenditure comprised within 7.10-11.30 Wh / tkm. While the return of the empty train is in the order of $12.42-17.73 \mathrm{Wh} / \mathrm{tkm}$.

The calculation results of the empirical indicator of electricity consumption for coal transportation by rail is presented in Table 2. Column 2 shows the calculated energy consumption for routes in Table 1 in the Polish conditions, column 3 - calculated indicator for routes from Table 1 (Polish conditions). The next step was to recalculate the indicator for routes with a distance of 100 $\mathrm{km}$ (column 4). Due to the fact that the average transport distance from Kuzbass to Poland is approx. five thousand $\mathrm{km}$, also the indicator for that distance in the Polish conditions was calculated (column 5).

The last line of Table 2 presents the calculation of the rate of electricity consumption for coal transportation by rail in Russian conditions. Data for calculations is reproduced from [34]. The paper [34] presents the results of studies on the consumption of electricity for freight trains weighing about 4.7 thousand ton over a test distance.

In the absence of information on energy consumption in trains without a load, the proportions of mass and energy, such as the Polish conditions, were adopted.

As shown in Table 2, the rate of electricity consumption for steam coal imports (col. 5) comprises in the range $9.22-14.45 \%$. It has been calculated for the transport of steam coal with a calorific value of 22 $\mathrm{MJ} / \mathrm{kg}$ and power plant efficiency of $38 \%$.

Table 2. Rate of electricity consumption for hard coal transportation by rail - calculations

\begin{tabular}{|c|c|c|c|c|}
\hline \multirow[b]{2}{*}{ Route } & $\begin{array}{l}\text { Route: } \\
\text { Out }+ \\
\text { Return }\end{array}$ & \multicolumn{3}{|c|}{$\begin{array}{c}\text { Rate of electricity } \\
\text { consumption for hard } \\
\text { coal transportation, } \%\end{array}$} \\
\hline & $\begin{array}{c}\mathrm{MWh} / \mathrm{t} \\
\mathrm{km}\end{array}$ & $\begin{array}{c}\text { Route: } \\
\text { Out } \\
+ \\
\text { Return }\end{array}$ & $100 \mathrm{~km}$ & $\begin{array}{c}5000 \\
\mathrm{~km}\end{array}$ \\
\hline 1 & 2 & 3 & 4 & 5 \\
\hline \multicolumn{5}{|c|}{ Poland } \\
\hline $\begin{array}{c}\text { Tarnowskie G.- } \\
\text { Gdynia }\end{array}$ & 22.7 & 0.92 & 0.19 & 9.71 \\
\hline $\begin{array}{l}\text { Warszawa - } \\
\text { Poznań }\end{array}$ & 11.3 & 0.72 & 0.25 & 12.35 \\
\hline Kraków - Medyka & 9.8 & 0.35 & 0.15 & 7.40 \\
\hline $\begin{array}{c}\text { Warszawa O. - } \\
\text { Łazy }\end{array}$ & 10.0 & 0.40 & 0.15 & 7.41 \\
\hline \multicolumn{3}{|c|}{ Average: } & 0.18 & 9.22 \\
\hline \multicolumn{5}{|c|}{ The Russian Federation } \\
\hline $\begin{array}{l}\text { Kuzbass - Polish } \\
\text { rail border } \\
\text { crossing }\end{array}$ & 33.8 & - & 0.29 & 14.45 \\
\hline
\end{tabular}

In the next step of the analysis, empirical indicator of electricity consumption for the transport of coal intended to produce $1 \mathrm{MWh}$ depending on the efficiency of the power plant was calculated. The calculation results are presented in Table 3. Hard coal-fired power plants in Poland have different efficiency and burn coal with different quality parameters [8]. It was therefore assumed that in the plants with different efficiency levels coal with a calorific value of $22 \mathrm{MJ} / \mathrm{kg}$ will be burned. The adopted value is the average calorific value of coal delivered to the Polish energy sector.

Table 3 shows the change in the indicator of electricity consumption for coal transportation from the Russian Federation to Poland (distance $5000 \mathrm{~km}$ ), according to the Polish (column 3) and Russian (column 4) data. For comparison, the last column presents the calculated rate of transport of coal from Polish mines to the Polish power plants over a distance of $300 \mathrm{~km}$. This is the average distance of transport of steam coal in Poland from the producer to the power plant. 
Table 3 Rate of electricity consumption for rail transport to produce $1 \mathrm{MWh}$ depending on the efficiency of power plants, steam coal $\mathrm{Q}=22 \mathrm{MJ} / \mathrm{kg}$

\begin{tabular}{|c|c|c|c|c|}
\hline \multirow{3}{*}{$\begin{array}{l}\text { The } \\
\text { efficiency } \\
\text { of hard } \\
\text { coal-fired } \\
\text { power } \\
\text { plant }\end{array}$} & \multirow{3}{*}{$\begin{array}{l}\text { The } \\
\text { quantity } \\
\text { of hard } \\
\text { coal to } \\
\text { produce } \\
1 \text { MWh }\end{array}$} & \multicolumn{3}{|c|}{ Rail transport } \\
\hline & & \multicolumn{2}{|c|}{$\begin{array}{l}\text { The Russian Fed., } \\
5000 \mathrm{~km}\end{array}$} & $\begin{array}{l}\text { Poland, } \\
300 \mathrm{~km}\end{array}$ \\
\hline & & $\begin{array}{c}\text { According } \\
\text { to Polish } \\
\text { data }\end{array}$ & $\begin{array}{c}\text { According } \\
\text { to Russian } \\
\text { data }\end{array}$ & $\begin{array}{c}\text { According } \\
\text { to Polish } \\
\text { data }\end{array}$ \\
\hline 1 & 2 & 3 & 4 & 5 \\
\hline$\%$ & Mt & \multicolumn{3}{|c|}{$\%$} \\
\hline 32 & 0.511 & 10.93 & 17.14 & 0.66 \\
\hline 34 & 0.481 & 10.29 & 16.13 & 0.62 \\
\hline 36 & 0.455 & 9.73 & 15.26 & 0.58 \\
\hline 38 & 0.431 & 9.22 & 14.45 & 0.55 \\
\hline 40 & 0.409 & 8.75 & 13.72 & 0.52 \\
\hline 42 & 0.390 & 8.34 & 13.08 & 0.50 \\
\hline 44 & 0.372 & 7.96 & 12.48 & 0.48 \\
\hline 46 & 0.356 & 7.61 & 11.94 & 0.46 \\
\hline
\end{tabular}

Comparing columns 4 and 5 with each other, one can see how significant is the energy expenditure associated with the import of coal from the Russian Federation to Poland. For a typical average power plant efficiency of $36-38 \%$, the energy consumption of coal imported from the Russian Federation will be in the area of 9.22-15.26\%. However, in the case of deliveries of steam coal from Polish mines it will be within the range $0.55-0.58 \%$. This comparison shows how much of a waste of energy we have to deal with when it comes to the imports of coal. In the transport of steam coal from Polish producers to the power plants it is almost negligible.

Taking into account the requirements of the current climate package, producing $1 \mathrm{MWh}$ from hard coal will emit 1.8 tonnes of $\mathrm{CO}_{2}$. In the light of current requirements to reduce $\mathrm{CO}_{2}$ emissions in the European Union, this factor should also be taken into account.

\section{Summary}

Coal is one of the most important energy sources in the world. Its share of the global energy consumption in 2014 was $30 \%$ (4.01 billion toe). According to forecasts for 2035, the use of coal will increase by 274 million toe, and its share in the energy balance of the world will fall.

The main objective of the article was to calculate the index describing what part of the energy contained in the coal transported on a particular route is consumed by the train carrying it.

On the basis of analysis of steam coal imports from the years 2004-2014, it was assumed that coal will be imported to Poland by rail from Russia's Kuznetsk Basin.

In order to estimate energy expenditure, information about energy consumption by freight trains on the Russian market was used. On the basis of this information, the amount of energy required for the transport of steam coal in relation to the energy contained in the transported fuel and burned in the power plants with specific technical parameters, was determined.

As a result of the calculation, it was found that the rate of energy consumption for transport of imported coal will be in the range of $9.22-15.26 \%$. In the case of deliveries of steam coal from Polish producers to the power plants the calculated rate changes within the range of 0.55 $0.58 \%$. It can be assumed that the parameter of energy consumption in the transport of steam coal within Poland is negligible because of its low value.

Large level of this ratio (a large share of the energy used for transport in relation to the energy contained in the transported fuel) negatively affects the assessment of the transport of fuels from great distances.

\section{Acknowledgments}

Publication prepared within the statutory research of The Mineral and Energy Economy Research Institute of the Polish Academy of Sciences.

\section{References}

1. BP Energy Outlook 2035 (BP, 2016, available at: http:/www.bp.com/energyoutlook; 12-04-2016)

2. Annual Reports, Facts and trends (Verein der Kohleimporteure, Hamburg, Editions of years 20062015, available at: http://www.kohlenimporteure.de/home.html; 12-042016)

3. Coal Information (IEA, Paris, Editions of years 20042015)

4. IDA JSC, Podstawowe informacje o rynku oraz sektorze węgla kamiennego (IDA JSC Branch Office in Katowice within the framework of the "Programme of statistical surveys" - a statistical survey "Mining of hard coal and lignite" conducted by the Ministry of Economy, Katowice, Editions of years 2012-2016)

5. W. Blaschke, L. Gawlik and U. Lorenz, In: Mat. XIV Konf. „Aktualia i perspektywy gospodarki surowcami mineralnymi", Sympozja i Konferencje 63, 15-27 (2004)

6. J. Szlązak, Restrukturyzacja górnictwa węgla kamiennego $w$ Polsce $w$ latach 1990-2002 (Biblioteka SEP, Kraków, 2004)

7. U. Lorenz, Gospodarka węglem kamiennym energetycznym (IGSMiE PAN, Kraków, 2010)

8. Z. Grudziński, Metody oceny konkurencyjności krajowego wegla kamiennego do produkcji energii 
elektrycznej, (Studia, Rozprawy, Monografie 180, 2012)

9. T. Olkuski, Analiza produkcji węgla kamiennego $i$ jego wykorzystanie $w$ wytwarzaniu energii elektrycznej, (Studia, Rozprawy, Monografie 174, 2012)

10. Dz. U. [Journal of Law] of 1997, No 157, Item 1027 (www.isap.sejm.gov.pl)

11. Dz. U. [Journal of Law] of 2001, No 47, Item 477, as amended (www.isap.sejm.gov.pl)

12. Dz. U. [Journal of Law] of 2001, No 123, Item 1352, as amended (www.isap.sejm.gov.pl)

13. Dz. U. [Journal of Law] of 2002, No 125, Item 1063 (www.isap.sejm.gov.pl)

14. M.P. [Official Journal of the Republic of Poland Monitor Polski] of 1999, No 3, Item 14 (www.isap.sejm.gov.pl)

15. Dz. U. [Journal of Law] of 2001, No 156, Item 826 (www.isap.sejm.gov.pl)

16. Dz. U. [Journal of Law] of 2001, No 156, Item 1825 (www.isap.sejm.gov.pl)

17. Dz. U. [Journal of Law] of 1999, No 83, Item 933 (www.isap.sejm.gov.pl)

18. Dz. U. [Journal of Law] of 2001, No 16, Item 180 (www.isap.sejm.gov.pl)

19. Dz. U. [Journal of Law] of 2000, No 105, Item 1116 (www.isap.sejm.gov.pl)

20. Dz. U. [Journal of Law] of 2004, No 90, Item 959 (www.isap.sejm.gov.pl)

21. U. Lorenz, Przegląd Górniczy, 7-8, 314-321 (2011)

22. T. Olkuski, Gospodarka Surowcami Mineralnymi Mineral Resources Management 29(3), 115-130 (2013)

23. K. Stala-Szlugaj, Polish import of steam coal from the East (CIS) in the year 1990-2011, (Studia, Rozprawy, Monografie 179, 2012)

24. K. Stala-Szlugaj, Przegląd Górniczy (to be published, 2016)

25. Taylor Z. Rozwój i regres sieci kolejowej w Polsce, (IGiPZ PAN, Monografie 7, 2007)

26. Transport - activity results (Central Statistical Office of Poland, Warszawa, Editiond of years 2005-2015)

27. Socjalno-ekonomiczeskoje polorhzenije Rossii (in Russian) (Russian Federation - Federal State Statistics Service, Editions of years 2004-2016, available

http://www.gks.ru/wps/wcm/connect/rosstat main/ro sstat/ru/statistics/publications/catalog/doc $1 \overline{1400869}$ 22125; 12-04-2016)

28. http://cargo.rzd.ru/static/public/ru?STRUCTURE ID $=5140 \&$ layer $\mathrm{id}=3290 \&$ refererLayerId $=3290 \& \mathrm{id}=2$ 178 (Available at: 12-04-2016)

29. http://railsite.ru/poluvagon.php (Available at: 12-042016)

30. http://www.csrgc.com.cn/g981/s2780/t248208.aspx (Available at: 12-04-2016)

31. https://www.ihha.net/sites/default/files/heavy $\% 20$ hau $1 \% 20$ operations $\% 20$ in $\% 20$ south $\% 20$ africa $\% 20 \mathrm{wc} \% 2$ 0kuys\%20110616 f.pdf (Available at: 12-04-2016)

32. http://www.lwv-bf.org/Coal Train_Fact Check.pdf (Available at: 12-04-2016)
33. http://www.minerals.org.au/resources/coal/exports/fa cts and figures (Available at: 12-04-2016)

34. W.P. Mogila, Massa, dlina i skorost dwirhzenija gruzowych pojezdow (in Russian) (Publ. DWGUPS, Chabarowsk, 2nd ed., revised and enlarged, 2013)

35. W. Wasilewicz, Transport Szynowy, 9, (1974)

36. J. Podoski, J. Kacprzak and J. Mysłek, Zasady trakcji elektrycznej (in Polish) (WKŁ, Warszawa, 1980)

37. A. Rojek, Tabor i trakcja kolejowa (in Polish) (PKP, Warszawa, 2010)

38. A. Szeląg and L. Mierzejewski, Ground transportation systems (The Wiley Encyclopedia of Electrical and Electronic Engineering, New York, Supplement, 2000)

39. R. Burak-Romanowski, and K. Wozniak, Czasopismo Techniczne - Technical Transactions, 108, 13, 13-29 (2011) 